\title{
Analysis of maternal mortality at a government teaching hospital GMKMCH, Salem, Tamil Nadu, India: a retrospective study
}

\author{
Sridevi G., Shanmugavadivu L.*
} Department of Obstetrics and Gynecology, Government Mohan Kumaramangalam Medical College Hospital, Salem,
Tamil Nadu, India

Received: 08 October 2018

Accepted: 01 November 2018

\section{*Correspondence:}

Dr. Shanmugavadivu L.,

E-mail: dr.vadivu@yahoo.com

Copyright: (c) the author(s), publisher and licensee Medip Academy. This is an open-access article distributed under the terms of the Creative Commons Attribution Non-Commercial License, which permits unrestricted non-commercial use, distribution, and reproduction in any medium, provided the original work is properly cited.

\begin{abstract}
Background: Mother is the pillar of the family. Maternal death is a great loss to the baby, family, society and country. Pregnancy although being considered as a physiological state carries risk of serious maternal morbidity and mortality. This is due to various complications that may occur during pregnancy, labour or thereafter. Maternal mortality ratio is a very sensitive index that reflects the quality of healthcare provided by the community to the women population.

Methods: A retrospective study of 204 maternal deaths over a period of 56 months from July 2013 -february 2018. Demographic data were collected from maternal death review form and records. Data studied and analyzed.

Results: During the study period, there were 33968 deliveries and 204 maternal deaths with a MMR of $600.5 / 1,00,000$ live births. Eclampsia was the leading direct cause of death. Anemia was the leading indirect cause of death. Most of the women died within 24 hours of admission suggesting that majority of patients reached the tertiary care hospital quite late. Majority of deaths occurred in the age group of 20-30 years and in postpartum period.

Conclusions: Most maternal deaths are preventable by optimal utilization of existing $\mathrm{MCH}$ facilities, identifying the bottleneck in health delivery system, early identification of high-risk pregnancy and therein timely referral to tertiary care centre.
\end{abstract}

Keywords: Anaemia, Eclampsia, Maternal death

\section{INTRODUCTION}

Maternal mortality is defined as the death of any woman while being pregnant or within 42 completed days of termination of pregnancy, irrespective of the duration or site of pregnancy, from any cause related to or aggravated by pregnancy but not from accidental or incidental cause. ${ }^{1}$

Maternal mortality ratio is defined internationally as maternal deaths per 1, 00,000 live births. India is among the countries which has a very high maternal mortality ratio. Maternal Mortality ratio was 2000 per 1, 00,000 live births in 1938 which declined to 1000 per $1,00,000$ live births in 1951 and dropped down to 540 in $1999 .^{2}$
Currently it is estimated to be 174 per 1,00,000 live births which is far above the goal of 100 per 1,00,000 live births as per the agenda of Millennium Development Goals(MDG). ${ }^{3}$.MMR averages at 27/1, 00,000 live births in developed countries to 480/1, 00,000 live births in developing countries.

Global maternal mortality is at 529,000 women per year of which only $1 \%$ death occurred in developed countries. ${ }^{4}$ The high number of maternal deaths in some areas reflect inequality in access to health services and highlight the gap between rich and poor. Hence the present study was conducted to review the existing maternal mortality ratio and to find out the cause of maternal death at tertiary care teaching hospital so that the corrective steps can be taken 
to reach the goal within the stipulated time frame as most of the deaths are preventable.

\section{METHODS}

Type of study: Retrospective study.

The present study was a retrospective analysis conducted in the department of Obstet and Gynaecol of GMKMCH, Salem, Tamil Nadu, India. Data regarding maternal mortality was collected from medical record section of our hospital. The details of maternal death over a period of 56 months from July 2013 to February 2018 was collected and analyzed with respect to the following epidemiological parameters: distribution of maternal death in relation to age, parity index, period of death, referral status, mode of delivery and cause of death.

\section{Inclusion criteria}

- All maternal deaths during the period of 56 months from July 2013 to February 2018 was included for the study.

\section{Exclusion criteria}

- Brought dead cases and death due to suicide and homicide was excluded from the study.

The angle between the ultrasound beam and direction of blood flow was maintained below 450 for umbilical artery. The umbilical artery was studied in a free loop. Umblical artery (UA) systolic diastolic ratio > 2SD above mean or absent or reversed end diastolic flow in umbilical artery was taken as abnormal. UA PI and UA RI were measured and value $>2 \mathrm{SD}$ was taken as abnormal. The middle cerebral artery was visualised at the circle of Willis and was insonated soon after its origin from internal carotid artery and the angle of insonation kept close to 00 . The pulsatility index was measured and cerebroumblical PI ratio calculated. MCA-RI was considered abnormal if measurement was 2 SD below the mean. All the ultrasound evaluations were done by a single obstetrician with expertise in Doppler sonography.

Results were analysed by using percentage and proportion.

\section{RESULTS}

In the present study there was 204 maternal deaths for 33968 deliveries giving MMR of 600.5 per $1,00,000$ live births which is higher than the national average. GMKMCH being teaching institute and tertiary care center we receive many complicated cases from rural places.

Admission of moribund cases from periphery has reflected the high mortality ratio like other teaching institutes in India. The results were tabulated based on age, mode of delivery, period of gestation, parity index and cause of death (Table 1).

Table 1: Maternal death year-wise.

\begin{tabular}{|llll|}
\hline Year & Total deliveries & Live births & $\begin{array}{l}\text { Maternal } \\
\text { death }\end{array}$ \\
\hline 2013 & 3359 & 3301 & 22 \\
\hline 2014 & 6976 & 6857 & 40 \\
\hline 2015 & 6944 & 6863 & 55 \\
\hline 2016 & 7687 & 7606 & 39 \\
\hline 2017 & 9017 & 8909 & 45 \\
\hline 2018 & 1215 & 1203 & 03 \\
\hline
\end{tabular}

$11.76 \%$ of maternal death occurred in the age group of less than 20 years (Table 2). In this age group incidence of preeclampsia and anemia was very high. Hence teenage marriages and pregnancy should be avoided.

Table 2: Age-wise distribution.

\begin{tabular}{|lll|}
\hline Age Group & $\begin{array}{l}\text { Number of } \\
\text { maternal deaths }\end{array}$ & Percentage \\
\hline$<20$ & 24 & 11.76 \\
\hline $21-30$ & 104 & 50.98 \\
\hline $31-40$ & 65 & 31.86 \\
\hline$>40$ & 11 & 5.39 \\
\hline
\end{tabular}

$62 \%$ of death occurred following caesarean section (Table-3).

Table 3: Mode of delivery.

$\begin{array}{lll}\text { Mode of delivery } & \text { Number of deaths } & \text { Percentage } \\ \text { Vaginal } & 57 & 38 \\ \text { Caesarean section } & 93 & 62\end{array}$

Our institution is a referral centre hence the caesarean section rate is $50 \%$. Since the caesarean section rate is high the incidence of maternal death following caesarean section is also high. $73.52 \%$ of deaths occurred in the post-partum period (Table 4).

Table 4: Period of Pregnancy at the time of death.

\begin{tabular}{|lll|}
\hline Period of pregnancy & $\begin{array}{l}\text { Number of } \\
\text { deaths }\end{array}$ & Percentage \\
\hline Antepartum & 48 & 23.52 \\
\hline Intrapartum & 6 & 2.95 \\
\hline Postpartum & 150 & 73.52 \\
\hline
\end{tabular}

By improving the antenatal care and institutional deliveries, death during antepartum and intrapartum period has reduced. Postnatal care and follow up of the patient need to be improved to reduce the deaths in the post-partum period.

$77.94 \%$ of deaths were in the referred patients (Table 5) (Table 6) (Table7). Since our institution is a tertiary care 
referral central $70 \%$ our admission are referral patients. So, the percentage of death in the referral patients in high.

Table 5: Referral status.

\begin{tabular}{lll} 
Referral Status & Number of deaths & Percentage \\
Referred & 159 & 77.94 \\
Internal & 45 & 22.05 \\
\hline
\end{tabular}

Table 6: Parity index.

\begin{tabular}{|lll|}
\hline Parity index & Number of deaths & Percentage \\
\hline Primi & 138 & 67.64 \\
\hline Multi & 66 & 32.35 \\
\hline
\end{tabular}

Table 7: Causes of maternal deaths.

\begin{tabular}{|lll|}
\hline Cause of maternal deaths & $\begin{array}{l}\text { Number of } \\
\text { deaths }\end{array}$ & Percentage \\
\hline Direct cause & 160 & 78.43 \\
\hline Indirect cause & 44 & 21.56 \\
\hline
\end{tabular}

$29.90 \%$ of deaths were due to preeclampsia and complications (Table 8).

Table 8: Direct cause.

\begin{tabular}{|lll|}
\hline Cause of death & $\begin{array}{l}\text { Number of } \\
\text { deaths }\end{array}$ & Percentage \\
\hline $\begin{array}{l}\text { Preeclampsia/ HELLP/ } \\
\text { Eclampsia }\end{array}$ & 61 & 29.90 \\
\hline PPH/ APH & 49 & 24.01 \\
\hline Sepsis/ MODS & 41 & 20.09 \\
\hline $\begin{array}{l}\text { Pulmonary embolism/ } \\
\text { amniotic embolism }\end{array}$ & 7 & 3.43 \\
\hline Ectopic pregnancy & 2 & 0.98 \\
\hline
\end{tabular}

Hemorrhage accounts to $24.01 \%$ of death. Following active management of third stage of labour universally and availability of oxytocics, the death due to hemorrhage is reduced. $10.29 \%$ of death were due to anemia (Table 9).

Table 9: Indirect cause.

\begin{tabular}{|lll|}
\hline Cause of death & Number of deaths & Percentage \\
\hline Anaemia & 21 & 10.29 \\
\hline Heart disease & 9 & 4.41 \\
\hline CVT/CVA & 8 & 3.92 \\
\hline Renal Failure & 1 & 0.49 \\
\hline Bronchopneumonia & 3 & 1.47 \\
\hline Hepatic failure & 1 & 0.49 \\
\hline HIV/HBV & 1 & 0.49 \\
\hline
\end{tabular}

\section{DISCUSSION}

In India most of the maternal death take place in institutions, more so in government teaching hospitals. In present study the maternal mortality ratio was 600.5/
$1,00,000$ live birth which is comparable with the study done by Malipatil.P et al in 2016 where the MMR is $586 / 1,00,000$ live birth. ${ }^{5}$

In present study the maternal death is more in the age group of 21-30 years which is $50.98 \%$ which is comparable to the study done by Kaur et al which showed $51.8 \%$ (6) .and also comparable to the study done by Sengupta et al which observed that $61 \%$ of death occurred between the age group of 21-30 years. ${ }^{7}$

In present study $62 \%$ of maternal death occurred following caesarean section which varied from the study done by Malipatil. P et al which showed $16.9 \%$ of death following caesarean section. ${ }^{5}$ Similarly it varied from the study done by Madhuri Badrinath et al which showed $20 \%$ of death following caesarean section. ${ }^{8}$

In present study postpartum death contributed to $73.52 \%$ which is comparable to study done by Malipatil. P et al which showed $60.8 \% .^{5}$ Similarly, another study done by Purandare et al showed $73.33 \%$ death were in postpartum period. ${ }^{9}$

In present study the death in primigravida is $67.64 \%$ which is comparable with the study done by Ratan Das et al which showed $63.28 \%$ of death in primigravida. ${ }^{10}$

In present study $78.43 \%$ of death were due to direct cause which is comparable with study done by Ratan Das et al which showed $81.64 \%$ of death were due to direct causes. ${ }^{10}$ It is also comparable with study done by Surekha et al which showed $61.51 \%$ of death were due to direct causes and study done by Chakraborty. S et al which showed $60-71 \%$ of death were due to direct causes. ${ }^{11,12}$ In present study major cause of maternal death was preeclampsia and eclampsia which contribute to $29.90 \%$ which is comparable with study by Chakraborty. S et al which showed $27.63 \%$ were due to preeclampsia and eclampsia. ${ }^{12}$ Similarly study done by Madhuri Badrinath et al showed $28.8 \%$ of death were due to preeclampsia and eclampsia (8). Similarly, study done by Surekha et al showed $28.19 \%$ of death were due to eclampsia and preeclampsia. ${ }^{11}$

\section{CONCLUSION}

Present study shows preeclampsia and its related complications and obstetric haemorrhage, and sepsis are the leading causes of maternal death which are potentially preventable. Maternal death can be prevented by improving the health care facility in rural areas by ensuring round-the-clock availability of delivery facilities, life-saving drugs like injection magnesium sulphate, injection oxytocin, and tablet misoprostol can reduce the death due to eclampsia and $\mathrm{PPH}$.

Early detection of high-risk pregnancies and referring them to tertiary care centres at the earliest can reduce the complications and death. 
National Rural Health Mission plays a major role in reducing the maternal mortality by advocating institutional deliveries, timely referral of high-risk cases and tracking of high-risk cases.

Funding: No funding sources

Conflict of interest: None declared

Ethical approval: The study was approved by the Institutional Ethics Committee

\section{REFERENCES}

1. PARK K, Preventive medicine in Obstetrics, Paediatrics and Geriatrics, Park's Textbook of preventive and social medicine.

2. Govt. of India (1962) Report of the Health survey and Planning Committee, Vol. 1, Govt of India, Ministry of Health and Family Welfare (1984) Annual Report 1983-1984.

3. United Nations Millennium Development Goals Available at www.un.org/milleniumgoals

4. Mathai M, reviewing maternal death and complication to make pregnancy and child birth safer, Regional Health Forum WHO South East Asia Region 61:214.5.

5. Pushpanjali Malipatil CV. Maternal mortality at a government teaching hospital: a six-year duration study. Int J Reproduct, Contracep, Obstet Gynecol. 2016;5(3):890-3
6. Devinder K, Amrirpal K. A retrospective study of maternal mortality in government medical college. $\mathrm{J}$ Obstet Gynecol family Welfare. 1999;5:18-22.

7. Sengupta A. The study of maternal mortality and morbidity in a North Indian Hospital-A 9 years Review. J Obstet Gynec India. 1986: 394-400.

8. Badrinath M, Karekal SA. Maternal mortality: a retrospective study. Sepsis. 2015;5;10-3.

9. Purandare N, Singh A, Upadhyae Sa, Saraogi RM. Maternal Mortality at a referral Centre: a five-year study. J. obstetric Gynaecol India2007:57(3):248-50

10. Das R. Maternal mortality at a Teaching Hospital of Rural India: A retrospective study. Age. 2014;19(79):30-85.

11. Khandale SN, Kedar K. Analysis of maternal mortality: a retrospective study at tertiary care centre. Int J Reproduct Contracep Obstet Gynecol. 2017;6(4):1610-3.

12. Chakraborty S, Sebanti G. Maternal mortality rate and its causes-changing trends in Kolkata, India. IJRRMS. 2012;2(1):16-8.

Cite this article as: Sridevi G, Shanmugavadivu L. Analysis of maternal mortality at a government teaching hospital GMKMCH, Salem, Tamil Nadu, India: a retrospective study. Int J Reprod Contracept Obstet Gynecol 2018;7:5093-6. 